\title{
Phytoplankton community in the last undammed stretch of the Paraná River: considerations on the distance from the dam
}

\author{
Comunidade fitoplanctônica no último trecho livre de barramento do rio Paraná: \\ consideraçóes sobre a distância do represamento
}

Susicley Jati ${ }^{1 *}$, Jascieli Carla Bortolini ${ }^{2}$, Geovani Arnhold Moresco ${ }^{3}$,

Aline Caroline Magro de Paula ${ }^{3}$, Luzia Cleide Rodrigues ${ }^{1,3}$, Patricia Iatskiu ${ }^{3}$, Alfonso Pineda ${ }^{3}$, Bárbara Furigo Zanco ${ }^{3}$, Matheus Vieira da Silva ${ }^{4}$ and Yasmin Rodrigues Souza ${ }^{5}$

${ }^{1}$ Núcleo de Pesquisas em Limnologia, Ictiologia e Aquicultura - Nupélia, Universidade Estadual de Maringá - UEM, Av. Colombo, 5790, Bloco H-90, CEP 87020-900, Maringá, PR, Brazil

${ }^{2}$ Laboratório de Ficologia, Universidade Estadual do Oeste do Paraná - Unioeste, Rua Universitária, 2019, Jardim Universitário, CEP 85819-110, Cascavel, PR, Brazil

${ }^{3}$ Programa de Pós-graduação em Ecologia de Ambientes Aquáticos Continentais - PEA, Universidade Estadual de Maringá - UEM, Av. Colombo, 5790, CEP 87020-900, Maringá, PR, Brazil

${ }^{4}$ Graduação em Ciências Biológicas, Universidade Estadual de Maringá - UEM, Av. Colombo, 5790, CEP 87020-900, Maringá, PR, Brazil

${ }^{5}$ Graduação em Ciências Biológicas, Centro Universitário de Maringá - Unicesumar,

Av. Guedner, 1610, Jardim Aclimação, CEP 87050-900, Maringá, PR, Brazil

*e-mail: susi@nupelia.uem.br

Cite as: Jati, S. et al. Phytoplankton community in the last undammed stretch of the Paraná River: considerations on the distance from the dam. Acta Limnologica Brasiliensia, 2017, vol. 29, e112.

\begin{abstract}
Aim: To evaluate the influence of upstream reservoirs on the temporal and spatial variation of the phytoplankton community in the Paraná River channel and the importance of its main tributaries in reducing the oligotrophication process along this stretch of the river. Materials and Methods: Sampling of phytoplankton and physical and chemical variables was performed quarterly between August 2013 and May 2015, in the Paraná River main channel and in the mouth of the main tributaries, at the stretch located between downstream Porto Primavera reservoir and the backwaters of Itaipu reservoir. To summarize the variation of phytoplankton density in relation to the main physical and chemical variables, we performed a Redundancy Analysis (RDA). Results: A total of 214 taxa were identified throughout the study. We registered low values of phytoplankton species richness and abundance, which showed no patterns of temporal and spatial distribution, both for the Paraná River and the tributaries. However, RDA results showed spatial segregation among samples from the Paraná River main channel, such that the stretch located closer to the dam was associated with higher values of water transparency and Cyanobacteria density, exported by upstream reservoirs, whereas the middle and lower stretches were associated with higher phytoplankton complexity and higher nutrient concentration and turbidity. Conclusion: Through the analysis of the phytoplankton community we could verify a reduction in the effects of oligotrophication along the longitudinal axis of the Paraná River and the important role of the tributaries in diminishing this effect.
\end{abstract}

Keywords: planktonic algae; lotic system; oligotrophication; Porto Primavera reservoir; serial discontinuity. 
Resumo: Objetivo: Avaliar a extensão da influência dos reservatórios à montante sobre a variação temporal e espacial do fitoplâncton na calha do rio Paraná e a importância de seus principais tributários na diminuição do processo de oligotrofização neste trecho do rio. Materiais e Métodos: Foram realizadas amostragens trimestrais de fitoplâncton e variáveis físicas e químicas da água entre agosto de 2013 e maio de 2015, na calha do rio do rio Paraná e na foz de principais tributários, no trecho compreendido entre a jusante do reservatório de Porto Primavera e o remanso de Itaipu. Para sumarizar a variação da densidade fitoplanctônica em relação às principais variáveis físicas e químicas da água, foi aplicada uma Análise de Redundância (RDA). Resultados: Foram identificados 214 táxons durante o estudo. Para riqueza de espécies e densidade fitoplanctônica os valores encontrados foram baixos e sem padrão de distribuiçáo temporal ou espacial, tanto para o rio Paraná quanto para os tributários. No entanto, quando aplicada uma RDA aos dados foi possível verificar a segregação espacial na calha do rio Paraná, com o trecho próximo à barragem relacionado a maiores valores de transparência da água e densidade de Cyanobacteria, exportadas pelos reservatórios à montante. Enquanto que os trechos médio e inferior estiveram associados à maior complexidade do fitoplâncton e maiores concentraçôes de nutrientes e turbidez. Conclusáo: Por meio da análise da comunidade fitoplanctônica, foi possível verificar a diminuição do efeito de oligotrofizaçáo ao longo do eixo longitudinal do rio Paraná e o importante papel dos tributários para a diminuição deste efeito.

Palavras-chave: alga planctônica; sistema lótico; oligotrofização; reservatório de Porto Primavera; descontinuidade serial.

\section{Introduction}

The Paraná River is among the largest Brazilian rivers and is fragmented by reservoir constructions. The last undammed stretch of this entire basin is located at the Upper Paraná River region, between downstream Porto Primavera reservoir and the backwaters of Itaipu reservoir. This stretch is approximately $230 \mathrm{~km}$ long and has an extensive flood area located at the right margin, creating a mosaic of habitats which harbours great phytoplankton diversity (Train \& Rodrigues, 2004), constituting an important species pool at both local and regional scales.

Considering that this area is located downstream a series of cascading reservoirs, it is possible to test the theory proposed by Ward \& Stanford (1983), which suggests that upstream reservoirs disrupt the longitudinal continuum of the river and, consequently, in the areas situated immediately downstream, the attributes of the aquatic communities return to less complex stages of development in response to alterations in the physical and chemical water characteristics.

In fact, in this stretch of the Paraná River, at the region situated immediately downstream Porto Primavera reservoir, there was a drastic reduction in the values of suspended solids (Souza-Filho, 2016), with a consequent increase in water transparency and a decrease in nutrient concentration, causing an oligotrophication process resulting in profound alterations in all aquatic biota (Agostinho et al., 2008; Roberto et al., 2009; Thomaz et al., 2004; Bovo-Scomparin et al., 2013; Rodrigues et al., 2009, 2015). Therefore, reservoir construction is among the main causes of biodiversity loss in continental aquatic environments (Agostinho et al., 2004; Winemiller et al., 2016).

It is believed that a natural and gradual restoration of the river occurs from downstream reservoir. However, the presence of a sufficiently long and undammed stretch and lateral sources of energy and matter are necessary (Stanford \& Ward, 2001). Thus, sources of contribution such as tributaries (Matsuura et al., 2015; Portinho et al., 2016) and the floodplain, may cooperate for the physical, chemical and biological water characteristics to return to values close to those observed prior to the disruption of the river continuity. Nevertheless, depending on the magnitude of the impact and the geographic location of the fragmentation on the longitudinal axis of the river, some signs of disturbance may persist indefinitely (Stanford \& Ward, 2001).

Phytoplankton is considered a good indicator of environmental changes, both of natural and anthropogenic origin (Brasil \& Huszar, 2011), since they have a short life cycle and are capable of responding rapidly to physical and chemical environmental alterations. This community has been studied at the Upper Paraná River region, mainly in the floodplain, for approximately two decades, especially focusing on identifying the influence of the hydrosedimentological regime and the consequences of the anthropogenic impact on phytoplankton dispersal, establishment and development (Train \& Rodrigues, 1998; Borges \& Train, 2009; Bovo-Scomparin \& Train, 2008; Rodrigues et al., 2009, 2015; Bortolini et al., 2014a, b, 2016a, b). However, evaluating the direct 
magnitude of the impact of upstream reservoirs on this community still requires attention.

Considering the serial discontinuity, we expect that along the longitudinal axis of the Paraná River, between Porto Primavera reservoir and the backwaters of Itaipu reservoir, the phytoplankton community shows an increase in density and species richness with the increase in the distance from the reservoir and the contribution of the tributaries, with a consequent reduction in the effects of oligotrophication. Thus, we aimed to verify the magnitude of the influence of upstream reservoirs on the temporal and spatial distribution of phytoplankton composition, density, and species richness, along a stretch of the Paraná River, as well as verify the importance of the main tributaries in minimizing the physical, chemical and biological impacts caused by upstream reservoirs.

\section{Material and Methods}

\subsection{Study area}

The study area is located at the Upper Paraná River region, it is $230 \mathrm{~km}$ long and encompasses the stretch between downstream UHE Engenheiro Sérgio Motta reservoir (Porto Primavera) and the backwaters of Itaipu reservoir $\left(22^{\circ} 37^{\prime} \mathrm{S} 53^{\circ} 6^{\prime} \mathrm{W}\right.$ and $\left.24^{\circ} 03^{\prime} \mathrm{S} 54^{\circ} 15^{\prime} \mathrm{W}\right)$ (Figure 1). This stretch of the Paraná River generally flows north south/southeast in a broad anastomosing channel with reduced declivity $(0.09 \mathrm{~m} / \mathrm{km})$, through tropical-subtropical regions, and has monthly average temperatures of over $15^{\circ} \mathrm{C}$ and precipitation of over $1.400 \mathrm{~mm}$ /year (IBGE, 1990).

\subsection{Sampling and laboratory analyses}

Samplings were performed along 10 transects (right margin, center and left margin of the river) in the Paraná River main channel and also in the mouth of seven main tributaries (T1-Paranapanema River, T2-Baía River, T3-Ivinhema River, T4-Ivaí River, T5-Amambai River, T6-Iguatemi River, T7-Piquiri River) along the studied stretch. Samples were taken quarterly from August 2013 to May 2015.

For quantitative phytoplankton analysis, samples were taken directly at the subsurface with bottles and fixed in situ with acetic Lugol's solution. Qualitative samples were concomitantly obtained using a plankton net (15 $\mu \mathrm{m}$ mesh size) and preserved using Transeau solution (Bicudo \& Menezes, 2006), which were used to support species identification.

To calculate species richness, we considered the total number of taxa present in each quantitative sample. The frequency of occurrence of species (Constancy $=\mathrm{C}$ ) was calculated according to the categories proposed by Dajoz (2005): constant $(\mathrm{C} \geq 70 \%)$, common $(30 \geq \mathrm{C} \leq 70 \%)$, occasional $(10 \leq \mathrm{C} \leq 30)$ and rare $(\mathrm{C} \leq 10 \%)$ species.

Phytoplankton density was estimated using an inverted microscope, following the Utermöhl (1958) method. The sample volume to be sedimented was defined according to the concentration of algae and/or detritus present in the sample and the sedimentation time was of at least three hours for each centimeter of the chamber height (Margalef, 1983). Counting was performed in random fields until at least 100 individuals of the most frequent species was found, with an error of less than $20 \%$ and a confidence coefficient of 95\% (Lund et al., 1958), considering the species rarefaction curve. Density was estimated according to APHA (1995) and results were expressed in individuals (cells, coenobium, colonies, filaments) per milliliters, considering the forms that the algae are found in the nature.

Daily values of the Paraná River water level were provided by Itaipu Binacional and the National Water Agency of Brazil (ANA). We considered 3.5m as a reference value of the water level at the Paraná River at which bank overflow occurs, characterizing the high water period (flood), whereas below this water level, we considered that samples were taken during the low water period (drought) (Souza-Filho, 2009).

Concomitantly to phytoplankton samplings, physical and chemical variables of the water were measured, listed in Table 1 with their respective methodologies.

\subsection{Data analyses}

To analyse the distribution of phytoplankton density among the different environments we performed a Redundancy Analysis (RDA) (Legendre \& Legendre, 1998). Two matrices were used: the biological matrix containing the values of the density of phytoplankton groups and an explanatory matrix in which all measured environmental variables were included (dissolved oxygen, conductivity, turbidity, $\mathrm{pH}$, alkalinity, euphotic zone, maximum depth, total nitrogen and total phosphorus). The biological matrix was Hellinger-transformed. For the explanatory variables, we tested the Variance Inflation Factor (VIF) and select only the variables showing VIF $>10$. We analyzed the values of adjusted $\mathrm{R}^{2}$ and the significance of the components using $\mathrm{p}<0.05$. All analyses were performed using software 
R version 2.11.1 (R Development Core Team, 2013) and "vegan" package (Oksanen et al., 2013). Data from the transects in the Paraná River main channel and tributaries were organized according to the distance from Porto Primavera reservoir in: upper stretch (P1, P2, P3, T1 and T2), middle stretch (P4, P5, P6, P7, T3, T4 and T5) and lower stretch (P8, P9, P10, T6 and T7).

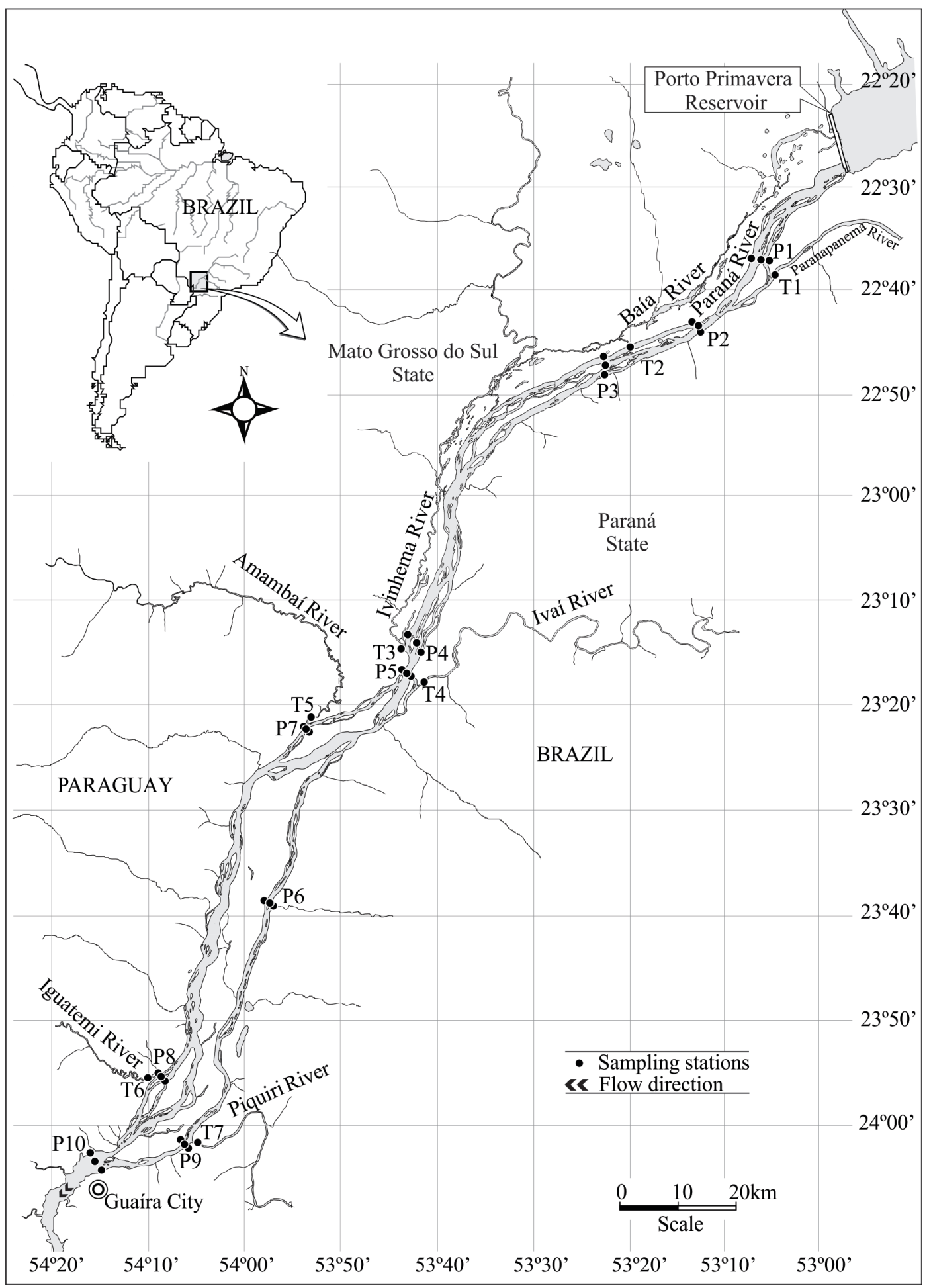

Figure 1. Map showing the sampling stations at the Upper Paraná River considering different distances from the Porto Primavera reservoir P1 to P10 - sampling stations at the right and left margins and at the center of the Paraná River main channel, T1 to T7 are the main tributaries. T1- Paranapanema River; T2- Baía River; T3- Ivinhema River; T4- Ivaí River; T5- Amambaí River; T6- Iguatemi River; T7- Piquiri River. 
Table 1. Methodologies used to determine water physical and chemical parameters.

\begin{tabular}{ccc}
\hline Variable/attribute & Method & Reference \\
\hline Maximum depth $\left(\mathrm{Z}_{\text {max, }} \mathrm{m}\right)$ & Ecobathymeter & Cole (1994) \\
Dissolved oxygen $\left(\mathrm{DO}, \mathrm{mg} \mathrm{L}^{-1}\right)$ & Thermistor coupled to Oximeter $\mathrm{YSI}$ (vertical profile) & \\
Euphotic zone $\left(\mathrm{Z}_{\mathrm{eu}, \mathrm{m}}\right)$ & 2.7 times the depth of the Secchi disk & \\
Turbidity $(\mathrm{Turb}, \mathrm{NTU})$ & Turbidimeter LaMotte & Golterman et al. (1978) \\
Conductivity $\left(\mathrm{Cond}, \mu \mathrm{S} . \mathrm{cm}^{-1}\right)$ & Portable digital potentiometer & Mackereth et al. (1978) \\
$\mathrm{pH}$ & Portable digital potentiometer & Mackereth et al. (1978) \\
Total phosphorus $\left(\mathrm{TP}, \mu \mathrm{L} \mathrm{L}^{-1}\right)$ & Spectrophotometer &
\end{tabular}

\section{Results}

\subsection{Environmental characterizarion of the Parana' River and tributaries}

Throughout the study period, typical floods were not observed in this stretch of the Paraná River (Figure 2). During the sampling period, the water level of the Paraná River was below $3.5 \mathrm{~m}$, which is considered the threshold value for bank overflow and beginning of the flooding process. The highest water level $(3.75 \mathrm{~m})$ was observed in March 2014, however, it lasted for only a few days and was not sufficient to characterize a high water period. The lowest water level was observed in July $2014(1.25 \mathrm{~m})$.

We observed low temporal variation of the abiotic parameters in all sampling stations. However, we observed a spatial variation, in which there was an increase in turbidity and nutrient concentrations with the increase in the distance from Porto Primavera reservoir. Tributaries located at the middle stretch of the Paraná River (T3, T4, T5) were the main nutrient contributors whereas T5 and T6 contributed the most for the high turbidity values found. Other limnological parameters did not show any patterns of spatial variation (Table 2 ).

\subsection{Phytoplankton community of the Paraná River and tributaries}

During the study period, we identified 214 phytoplankton taxa, distributed in 10 taxonomic groups. Chlorophyceae and Bacillariophyceae were the most representative groups with 62 and 58 taxa, respectively, followed by Cyanobacteria with 39 taxa. The most representative genera were Desmodesmus (Chodat) S.S. Na, T. Friedl \& E. Hegewald and Monoraphidium Komark.-Legnerov (both Chlorophyceae), Eunotia

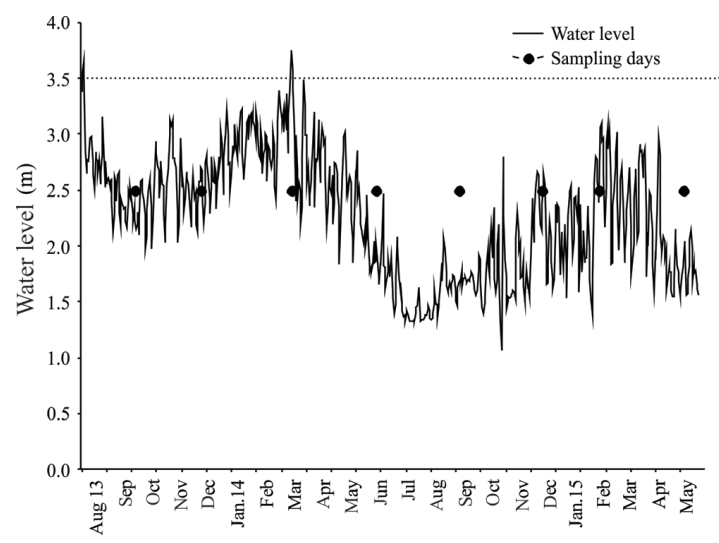

Figure 2. Water level of the Paraná River (continuous line) from August 2013 to May 2015. Points indicate sampling days. The dotted line indicates the limit $(3.5 \mathrm{~m})$ above which the high water period is considered.

Ehrenberg (Bacillariophyceae) and Trachelomonas Ehr. Emend. Deflandre (Euglenophycea).

We observed a high complexity (species richness) in the composition of taxonomic groups and an elevated contribution of rare species (96\% - 206 species) both in the Paraná River and in the tributaries. Unicellular flagellated cryptophyceans, represented by Cryptomonas marsonii Skuja (97\%) and Chrooomonas acuta Utermöhl (87\%), and flagellated chlorophycean Spermatozopsis exultans Korshikov (74\%) were considered constant species with a high frequency of occurrence. The chlorophyceans Chlamydomonas sp. (33\%) and Closteriopsis scolia Comas $(31 \%)$, and the pennate diatoms Cocconeis sp. (36\%), Acnanthidium minutissimum (Kütz.) Czarn. (36\%) and Fragilaria sp. (35\%) were considered common species.

Higher values of phytoplankton species richness were observed in the tributaries (mean of 22 taxa), whereas lower values were found in the Paraná River main channel (mean of 17 taxa). We observed low temporal and spatial variation in the number 
Table 2. Mean values and coefficient of variation (\% in parentheses) of abiotic variables measured in the Paraná River main channel and in its main tributaries from August 2013 to May 2015.

\begin{tabular}{|c|c|c|c|c|c|c|c|c|c|}
\hline $\begin{array}{l}\text { Sampling } \\
\text { station }\end{array}$ & $Z_{\text {max }}$ & $\mathrm{z}_{\mathrm{eu}}$ & TURB & DO & $\mathrm{pH}$ & COND & ALC & TN & TP \\
\hline P1 & $\begin{array}{c}2.3 \\
(32.0)\end{array}$ & $\begin{array}{c}6.3 \\
(33.5)\end{array}$ & $\begin{array}{c}1.9 \\
(44.4)\end{array}$ & $\begin{array}{c}7.8 \\
(9.5)\end{array}$ & $\begin{array}{c}7.5 \\
(2.9)\end{array}$ & $\begin{array}{l}64.9 \\
(7.8)\end{array}$ & $\begin{array}{l}624.0 \\
(25.9)\end{array}$ & $\begin{array}{c}739.9 \\
(26.4)\end{array}$ & $\begin{array}{c}13.9 \\
(104.6)\end{array}$ \\
\hline P2 & $\begin{array}{c}5.9 \\
(17.9)\end{array}$ & $\begin{array}{c}7.6 \\
(24.1)\end{array}$ & $\begin{array}{c}3.4 \\
(43.0)\end{array}$ & $\begin{array}{c}7.8 \\
(9.0)\end{array}$ & $\begin{array}{c}7.6 \\
(2.8)\end{array}$ & $\begin{array}{l}66.1 \\
(7.0)\end{array}$ & $\begin{array}{l}618.0 \\
(29.6)\end{array}$ & $\begin{array}{l}784.3 \\
(31.9)\end{array}$ & $\begin{array}{c}11.5 \\
(17.9)\end{array}$ \\
\hline P3 & $\begin{array}{c}3.1 \\
(40.0)\end{array}$ & $\begin{array}{c}5.7 \\
(39.6)\end{array}$ & $\begin{array}{c}3.4 \\
(48.6)\end{array}$ & $\begin{array}{l}7.8 \\
(9.5)\end{array}$ & $\begin{array}{c}7.5 \\
(2.3)\end{array}$ & $\begin{array}{l}63.6 \\
(5.3)\end{array}$ & $\begin{array}{l}548.5 \\
(30.8)\end{array}$ & $\begin{array}{l}726.2 \\
(32.4)\end{array}$ & $\begin{array}{l}13.6 \\
(20.9)\end{array}$ \\
\hline P4 & $\begin{array}{c}4.3 \\
(15.0)\end{array}$ & $\begin{array}{c}5.1 \\
(33.7)\end{array}$ & $\begin{array}{c}7.3 \\
(27.3)\end{array}$ & $\begin{array}{c}7.8 \\
(8.0)\end{array}$ & $\begin{array}{c}7.4 \\
(4.4)\end{array}$ & $\begin{array}{l}61.0 \\
(6.9)\end{array}$ & $\begin{array}{l}548.6 \\
(28.9)\end{array}$ & $\begin{array}{l}745.1 \\
(33.2)\end{array}$ & $\begin{array}{l}20.4 \\
(21.0)\end{array}$ \\
\hline P5 & $\begin{array}{c}5.7 \\
(11.2)\end{array}$ & $\begin{array}{r}5.3 \\
(32.5)\end{array}$ & $\begin{array}{c}7.8 \\
(20.5)\end{array}$ & $\begin{array}{c}7.6 \\
(10.2)\end{array}$ & $\begin{array}{c}7.3 \\
(2.8)\end{array}$ & $\begin{array}{c}57.9 \\
(5.2)\end{array}$ & $\begin{array}{l}522.2 \\
(32.9)\end{array}$ & $\begin{array}{l}745.3 \\
(35.0)\end{array}$ & $\begin{array}{c}20.2 \\
(20.2)\end{array}$ \\
\hline P6 & $\begin{array}{c}2.8 \\
(15.0)\end{array}$ & $\begin{array}{c}3.2 \\
(30.5)\end{array}$ & $\begin{array}{c}15.1 \\
(70.3)\end{array}$ & $\begin{array}{c}7.5 \\
(10.9)\end{array}$ & $\begin{array}{c}7.1 \\
(5.6)\end{array}$ & $\begin{array}{c}57.4 \\
(12.8)\end{array}$ & $\begin{array}{c}522.9 \\
(41.8)\end{array}$ & $\begin{array}{l}774.7 \\
(27.6)\end{array}$ & $\begin{array}{c}22.9 \\
(35.4)\end{array}$ \\
\hline P7 & $\begin{array}{c}3.1 \\
(16.8)\end{array}$ & $\begin{array}{c}3.5 \\
(40.7)\end{array}$ & $\begin{array}{c}11.5 \\
(26.6)\end{array}$ & $\begin{array}{c}7.4 \\
(10.2)\end{array}$ & $\begin{array}{c}7.1 \\
(6.8)\end{array}$ & $\begin{array}{c}55.8 \\
(16.2)\end{array}$ & $\begin{array}{l}504.6 \\
(21.8)\end{array}$ & $\begin{array}{l}797.5 \\
(38.5)\end{array}$ & $\begin{array}{l}23.7 \\
(32.6)\end{array}$ \\
\hline P8 & $\begin{array}{c}3.3 \\
(7.5)\end{array}$ & $\begin{array}{c}2.8 \\
(38.2)\end{array}$ & $\begin{array}{c}11.8 \\
(41.1)\end{array}$ & $\begin{array}{c}7.5 \\
(8.6)\end{array}$ & $\begin{array}{c}7.0 \\
(7.5)\end{array}$ & $\begin{array}{c}49.8 \\
(6.5)\end{array}$ & $\begin{array}{c}462.2 \\
(28.6)\end{array}$ & $\begin{array}{l}698.7 \\
(37.0)\end{array}$ & $\begin{array}{l}23.8 \\
(23.5)\end{array}$ \\
\hline P9 & $\begin{array}{c}2.1 \\
(7.1)\end{array}$ & $\begin{array}{c}3.1 \\
(37.0)\end{array}$ & $\begin{array}{c}10.7 \\
(46.2)\end{array}$ & $\begin{array}{c}7.8 \\
(10.0)\end{array}$ & $\begin{array}{c}7.1 \\
(7.6)\end{array}$ & $\begin{array}{l}62.5 \\
(4.7)\end{array}$ & $\begin{array}{l}584.8 \\
(30.3)\end{array}$ & $\begin{array}{l}875.8 \\
(34.3)\end{array}$ & $\begin{array}{c}22.2 \\
(21.4)\end{array}$ \\
\hline P10 & $\begin{array}{c}2.6 \\
(7.6)\end{array}$ & $\begin{array}{c}3.3 \\
(40.1)\end{array}$ & $\begin{array}{c}15.1 \\
(59.0)\end{array}$ & $\begin{array}{c}7.6 \\
(10.0)\end{array}$ & $\begin{array}{c}6.9 \\
(8.4)\end{array}$ & $\begin{array}{l}51.6 \\
(3.7)\end{array}$ & $\begin{array}{l}488.4 \\
(34.3)\end{array}$ & $\begin{array}{l}863.8 \\
(29.9)\end{array}$ & $\begin{array}{l}25.6 \\
(29.6)\end{array}$ \\
\hline $\mathrm{T} 1$ & $\begin{array}{c}5.1 \\
(73.4)\end{array}$ & $\begin{array}{c}5.6 \\
(75.4)\end{array}$ & $\begin{array}{c}8.5 \\
(50.1)\end{array}$ & $\begin{array}{c}10.1 \\
(62.5)\end{array}$ & $\begin{array}{c}9.5 \\
(59.4)\end{array}$ & $\begin{array}{c}88.2 \\
(55.6)\end{array}$ & $\begin{array}{l}771.3 \\
(42.6)\end{array}$ & $\begin{array}{l}1668.5 \\
(103.6)\end{array}$ & $\begin{array}{c}25.3 \\
(55.4)\end{array}$ \\
\hline $\mathrm{T} 2$ & $\begin{array}{c}3.9 \\
(140.3)\end{array}$ & $\begin{array}{r}8.7 \\
(172.1)\end{array}$ & $\begin{array}{c}6.4 \\
(76.2)\end{array}$ & $\begin{array}{c}8.2 \\
(57.7)\end{array}$ & $\begin{array}{c}8.2 \\
(59.5)\end{array}$ & $\begin{array}{c}29.5 \\
(38.7)\end{array}$ & $\begin{array}{l}216.9 \\
(40.7)\end{array}$ & $\begin{array}{l}756.7 \\
(21.6)\end{array}$ & $\begin{array}{c}32.6 \\
(39.0)\end{array}$ \\
\hline T3 & $\begin{array}{c}4.6 \\
(8.8)\end{array}$ & $\begin{array}{c}1.6 \\
(42.3)\end{array}$ & $\begin{array}{c}19.4 \\
(28.7)\end{array}$ & $\begin{array}{c}6.9 \\
(13.7)\end{array}$ & $\begin{array}{c}6.9 \\
(4.1)\end{array}$ & $\begin{array}{c}41.7 \\
(6.7)\end{array}$ & $\begin{array}{c}465.8 \\
(34.4)\end{array}$ & $\begin{array}{c}843.9 \\
(29.1)\end{array}$ & $\begin{array}{c}40.4 \\
(28.4)\end{array}$ \\
\hline $\mathrm{T} 4$ & $\begin{array}{c}5.6 \\
(25.4)\end{array}$ & $\begin{array}{c}1.8 \\
(39.2)\end{array}$ & $\begin{array}{c}22.3 \\
(85.4)\end{array}$ & $\begin{array}{c}7.9 \\
(8.9)\end{array}$ & $\begin{array}{c}7.0 \\
(9.5)\end{array}$ & $\begin{array}{c}59.3 \\
(12.0)\end{array}$ & $\begin{array}{c}534.3 \\
(32.5)\end{array}$ & $\begin{array}{r}1280.5 \\
(29.6)\end{array}$ & $\begin{array}{c}35.0 \\
(23.3)\end{array}$ \\
\hline T5 & $\begin{array}{c}3.8 \\
(17.8)\end{array}$ & $\begin{array}{c}1.2 \\
(51.6)\end{array}$ & $\begin{array}{c}37.0 \\
(77.3)\end{array}$ & $\begin{array}{r}6.7 \\
(13.5)\end{array}$ & $\begin{array}{c}6.6 \\
(6.3)\end{array}$ & $\begin{array}{c}34.6 \\
(13.1)\end{array}$ & $\begin{array}{c}326.0 \\
(29.9)\end{array}$ & $\begin{array}{l}932.7 \\
(27.0)\end{array}$ & $\begin{array}{c}32.4 \\
(32.3)\end{array}$ \\
\hline T6 & $\begin{array}{c}6.6 \\
(28.8)\end{array}$ & $\begin{array}{c}1.4 \\
(46.1)\end{array}$ & $\begin{array}{c}25.6 \\
(62.5)\end{array}$ & $\begin{array}{c}8.0 \\
(11.2)\end{array}$ & $\begin{array}{c}6.7 \\
(10.2)\end{array}$ & $\begin{array}{c}42.3 \\
(25.7)\end{array}$ & $\begin{array}{c}386.6 \\
(61.6)\end{array}$ & $\begin{array}{r}1006.1 \\
(31.5)\end{array}$ & $\begin{array}{c}27.6 \\
(28.8)\end{array}$ \\
\hline T7 & $\begin{array}{c}3.6 \\
(62.0)\end{array}$ & $\begin{array}{r}3.1 \\
(151.4)\end{array}$ & $\begin{array}{c}30.9 \\
(84.9)\end{array}$ & $\begin{array}{c}7.5 \\
(12.3)\end{array}$ & $\begin{array}{c}6.5 \\
(11.3)\end{array}$ & $\begin{array}{c}27.4 \\
(55.8)\end{array}$ & $\begin{array}{c}279.3 \\
(68.0)\end{array}$ & $\begin{array}{c}860.6 \\
(38.9)\end{array}$ & $\begin{array}{c}21.1 \\
(59.1)\end{array}$ \\
\hline
\end{tabular}

Maximum depth $\left(\mathrm{Z}_{\max }, \mathrm{m}\right)$; Euphotic zone $\left(\mathrm{Z}_{\mathrm{eu}}, \mathrm{m}\right)$; Turbidity (Turb, NTU); Dissolved oxygen (DO, mg. $\left.\mathrm{L}^{-1}\right)$; Conductivity (Cond, $\mu \mathrm{S} . \mathrm{cm}^{-1}$ ); Alkalinity (Alc., mEq l-1); Total nitrogen (TN, $\mu \mathrm{g} . \mathrm{L}^{-1}$ ); Total phosphorus (TP, $\mu \mathrm{g} \cdot \mathrm{L}^{-1}$ ). Ten sampling stations along the longitudinal axis of the Paraná River (P1-P10) and main tributaries (T1- Paranapanema River; T2- Baia; T3- Ivinhema River; T4- Ivai River; T5- Amambai River; T6- Iguatemi River; T7- River Piquiri).

of taxa among the sampled environments. Both in the Paraná River main channel and in the tributaries, there was a tendency of decrease in species richness in the sampling performed in May 2015 (Figures 3 and 4).

In the Paraná River main channel, classes Bacillariophyceae, Chlorophyceae, Cyanobacteria and Cryptophyceae were the most representative groups. The maximum phytoplankton richness (27 taxa) was observed in November 2014, at the right margin of $\mathrm{P} 7$, immediately below the mouth of the Amambaí River (T5). On the other hand, the lowest richness value ( 4 taxa) was registered at the left margin of P7 in May 2015. We did not observe any patterns of spatial or temporal distribution for phytoplankton species richness in the river channel (Figure 3).

In the tributaries, considering the phytoplankton richness, the most representative taxonomic classes were Bacillariophyceae, Chlorophyceae and Cryptophyceae. Specifically, besides de taxonomic groups previously mentioned, Cyanobacteria had an important contribution to the species richness in the Paranapanema River (T1) (Figure 2). The highest 

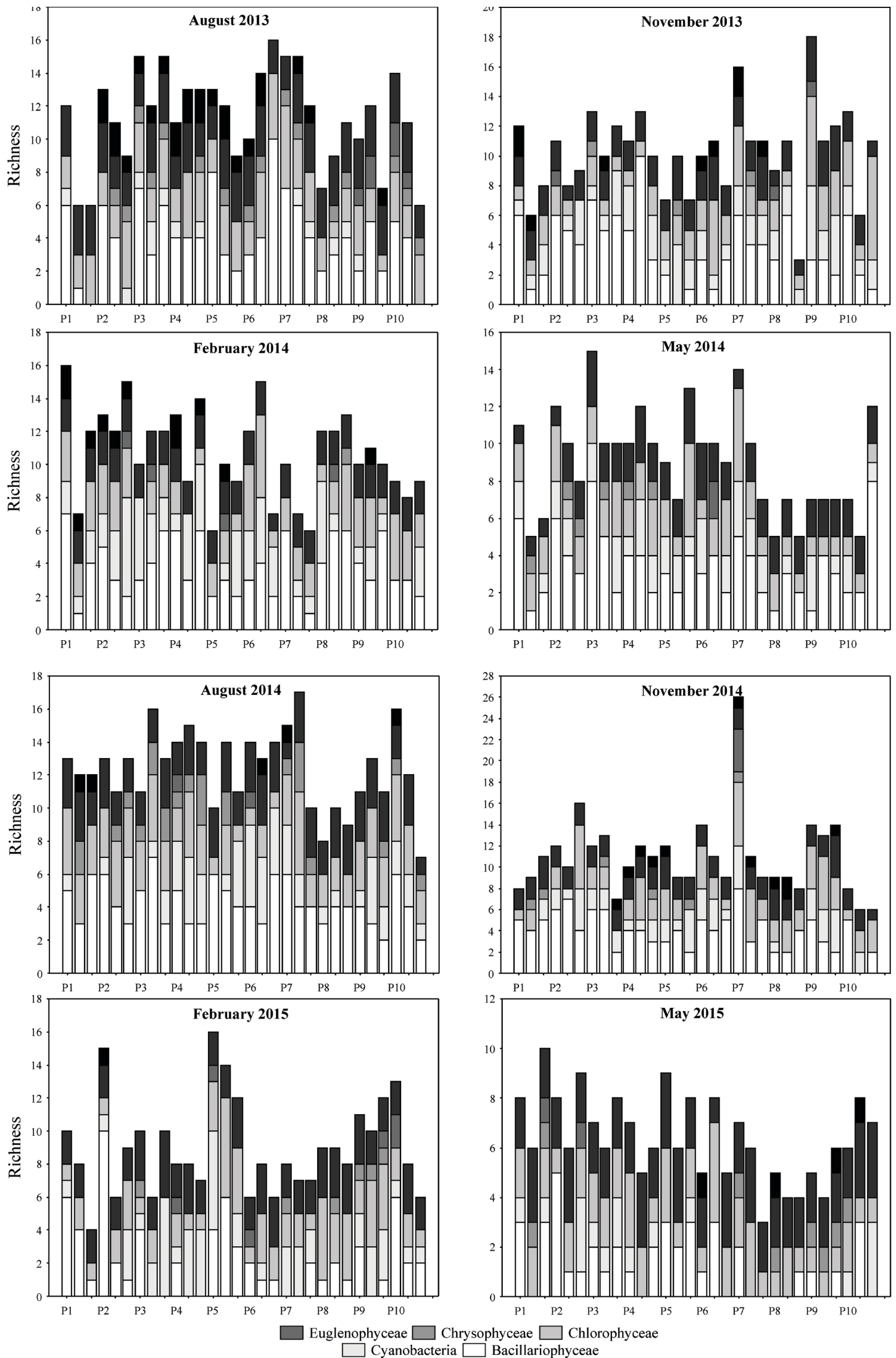

Figure 3. Richness of phytoplankton taxonomic groups in the Paraná River channel sampled quarterly from August 2013 to May 2015. P1 to P10 - transects sampled in the right and left margins and in the center of the Paraná River main channel. 
Jati, S. et al.
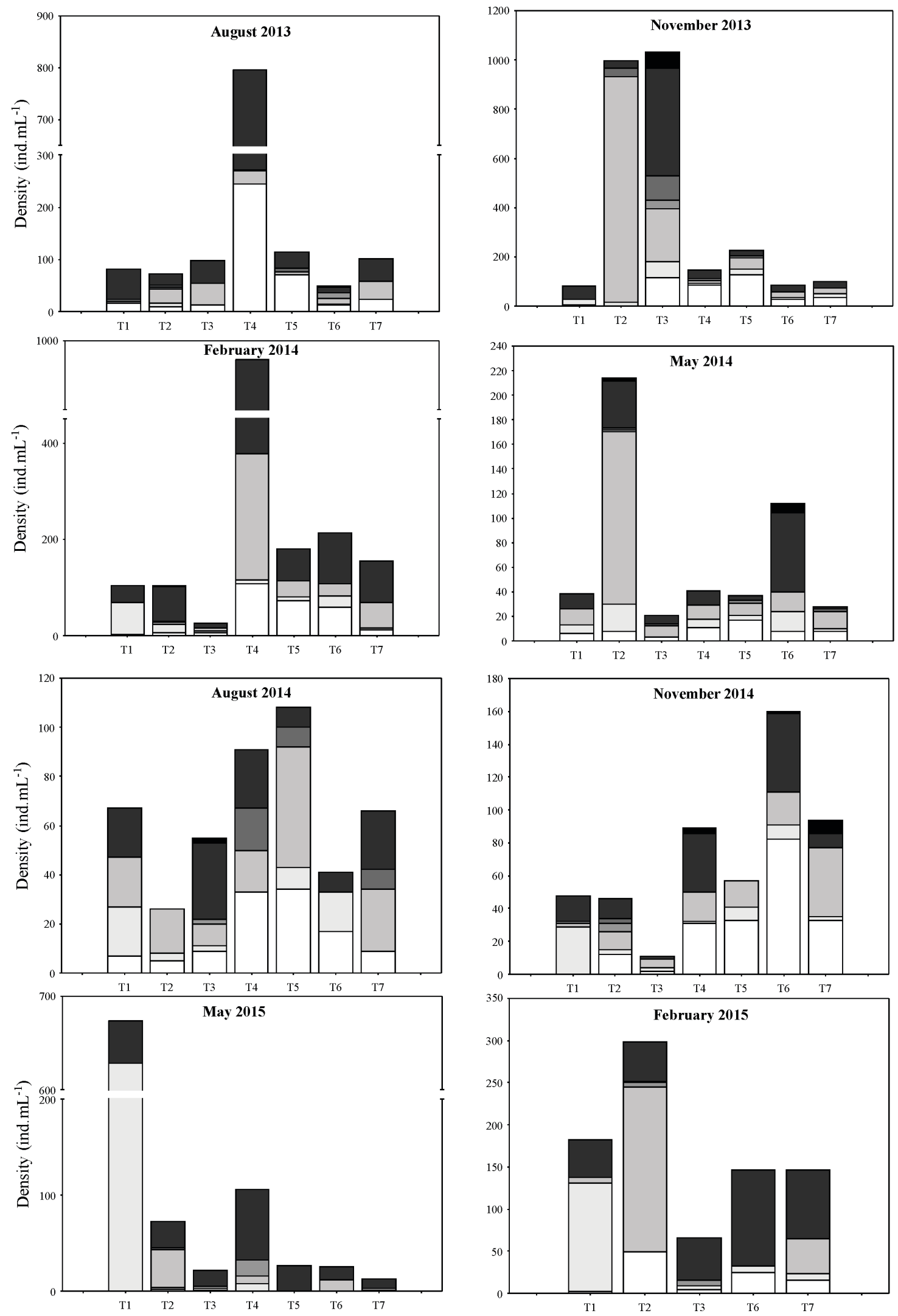

Euglenophyceae $\square$ Chrysophyceae $\square$ Chlorophyceae $\square$ Cyanobacteria $\square$ Bacillariophyceae

Figure 4. Richness of phytoplankton taxonomic groups in the main tributaries (T1 to T7) of the Paraná River sampled quarterly from August 2013 to May 2015. 
phytoplankton richness (29 taxa) was observed in the Ivinhema River (T3) in November 2013, whereas the lowest values were observed in May 2015, at the Amambai (T5) and Iguatemi (T7) rivers, with 1 and 2 taxa, respectively (Figure 4).

Regarding phytoplankton density, low values were registered and no temporal or spatial distribution pattern was observed neither for the Paraná River nor for the tributaries. Cyanobacteria (Microcysytis aeruginosa Kütz., Pseudanabaena mucicola (Hüb.-Pest. and Naum.) Bourr.) and Cryptophyceae (Cryptomonas marssonii, Chroomonas acuta) occurred in all sampling stations of the Paraná River. The highest density values of Cyanobacteria occurred during samplings performed in November 2013 (1200 ind. $\mathrm{mL}^{-1}$ ), February 2014 (842 ind. $\mathrm{mL}^{-1}$ ) and February 2015 (2256 ind. $\mathrm{mL}^{-1}$ ) and were registered at the sampling stations located at the left margin and at the center of the Paraná River. Cryptophyceae showed the highest value of this attribute in November 2014 at the left margin of sampling station P5 (495 ind. $\mathrm{mL}^{-1}$ ), but showed an important contribution in total phytoplankton density throughout the study period. Chlorophyceae (Spermatosopsis exultans and Chlamydomonas sp) showed the highest density values in August 2013, May 2014 and February 2015 along the longitudinal axis of the Paraná River (Figure 5).

Among the tributaries, most phytoplankton populations belonged to classes Cryptophyceae, Chlorophyceae, Bacillariophyceae and Cyanobacteria. Several other taxonomic groups, despite occurring in low densities, provided a greater complexity to sampling stations located at Baia (T2) and Ivinhema (T3) rivers. The highest phytoplankton density was registered in the Ivinhema River (T3) in November 2013 (1150 ind. $\mathrm{mL}^{-1}$ ), with Cryptophyceae and Chlorophyceae representing $42 \%$ and $21 \%$ of total phytoplankton density, respectively. Piquiri River (T6) showed the lowest temporal variation in phytoplankton density with low density values registered throughout the study period (Figure 6). Regarding the spatial distribution, tributaries located at the right margin of the Paraná River (Baia-T2, Ivinhema-T3, Amambai-T5 and Iguatemi-T7 rivers), showed higher density values than the ones located at the left margin (Ivaí-T4 and Piquiri-T6 rivers). Regarding both temporal and spatial variation, the Paranapanema River (T1) which is the first tributary located at the left margin of the Paraná River was an exception, and showed maximum density in May 2015 (674 ind. $\mathrm{mL}^{-1}$ ), with
93\% of the individuals belonging to Cyanobacteria (Microcystis aeruginosa Kütz and Pseudanabaena mucicola (Hüb.-Pest. e Naum.) Bourr.) (Figure 6).

During the study period, we detected the presence of Ceratium furcoides (Levander) Langhans (Dinophyceae) in the Paraná River main channel. Although this species occurred in low densities (P6 center: 2 ind. $\mathrm{mL}^{-1}$ in August 2014; P3 left margin: 3 ind. $\mathrm{mL}^{-1}$ in November 2014), its presence awakens attention since it is an exotic dinoflagellate species that has been registered as invasive in several Brazilian hydrographic basins.

Redundancy analysis (RDA) showed significant scores for the first two axes, which explained $22 \%$ of total data variability. This analysis evidenced a gradient in the distribution of the phytoplankton community along the longitudinal axis of the Paraná River, in response to the variation in environmental conditions caused by the existence of upstream reservoirs $(\mathrm{p}=0.005)$. Although we did not observe a conspicuous temporal variation, a spatial variation in phytoplankton density was evidenced, which segregated samples from the upper and middle stretches of the Paraná River at the left portion of the graph, where Cyanobacteria and Cryptophyceae densities were associated with higher values of water transparency, depth, conductivity, total nitrogen concentrations and alkalinity. Scores from Paranapanema River were grouped together with data from the upper stretch of the Paraná River and were associated with higher densities of Cyanobacteria, evidencing the interdependency of these data.

Samples from the lower stretch of the Paraná River were grouped at the right portion of the graph, and were associated with higher Chlorophyceae and Bacillariophyceae densities and higher phosphorus concentrations. It is important to highlight that the other tributaries (T2, T3, T4, T5, T6 e T7), mainly T7, were related to samples from the lower stretch of the Paraná River and higher phytoplankton densities, total phosphorus concentration and turbidity (Figure 7).

\section{Discussion}

The river flow regulation, decrease in flood duration and amplitude, besides the retention of particulate matter and nutrients by upstream reservoirs impose serious physical, chemical and biological modifications in the last undammed stretch of the Paraná River (Thomaz et al., 2004; Agostinho et al., 2008; Roberto et al., 2009; Rodrigues et al., 2009, 2015; Souza Filho, 2009, 

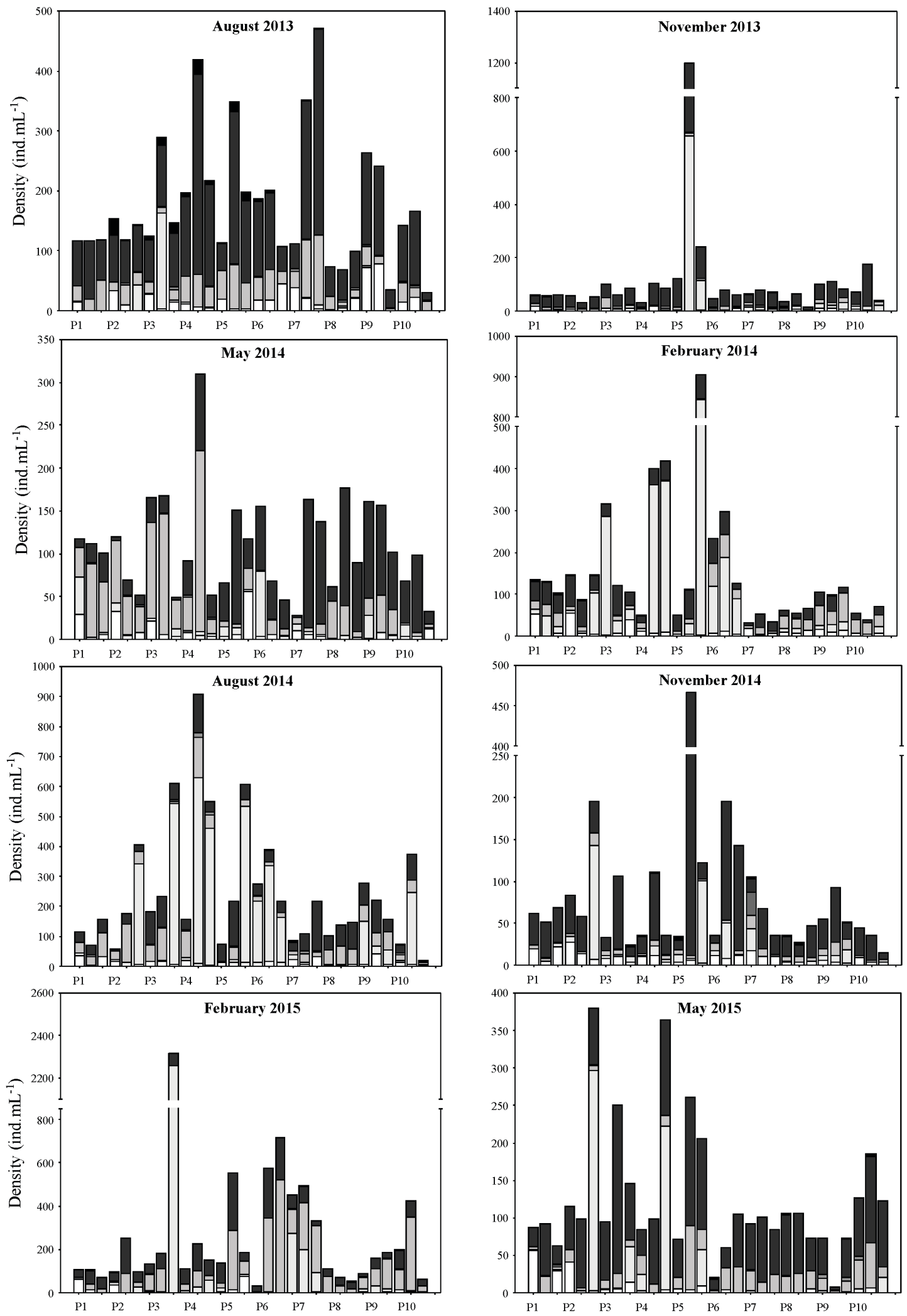

Others taxonomic groups $\square$ Cryptophyceae

Euglenophyceae $\square$ Chrysophyceae $\square$ Chlorophyceae

$\square$ Cyanobacteria $\square$ Bacillariophyceae

Figure 5. Density of phytoplankton taxonomic groups (ind. $\mathrm{ml}^{-1}$ ) in the Paraná River channel sampled quarterly from August of 2013 to May of 2015. P1 to P10 - transects sampled in the right and left margins and in the center of the Paraná River main channel. 
Phytoplankton community in the last undammed stretch of the Paraná River...
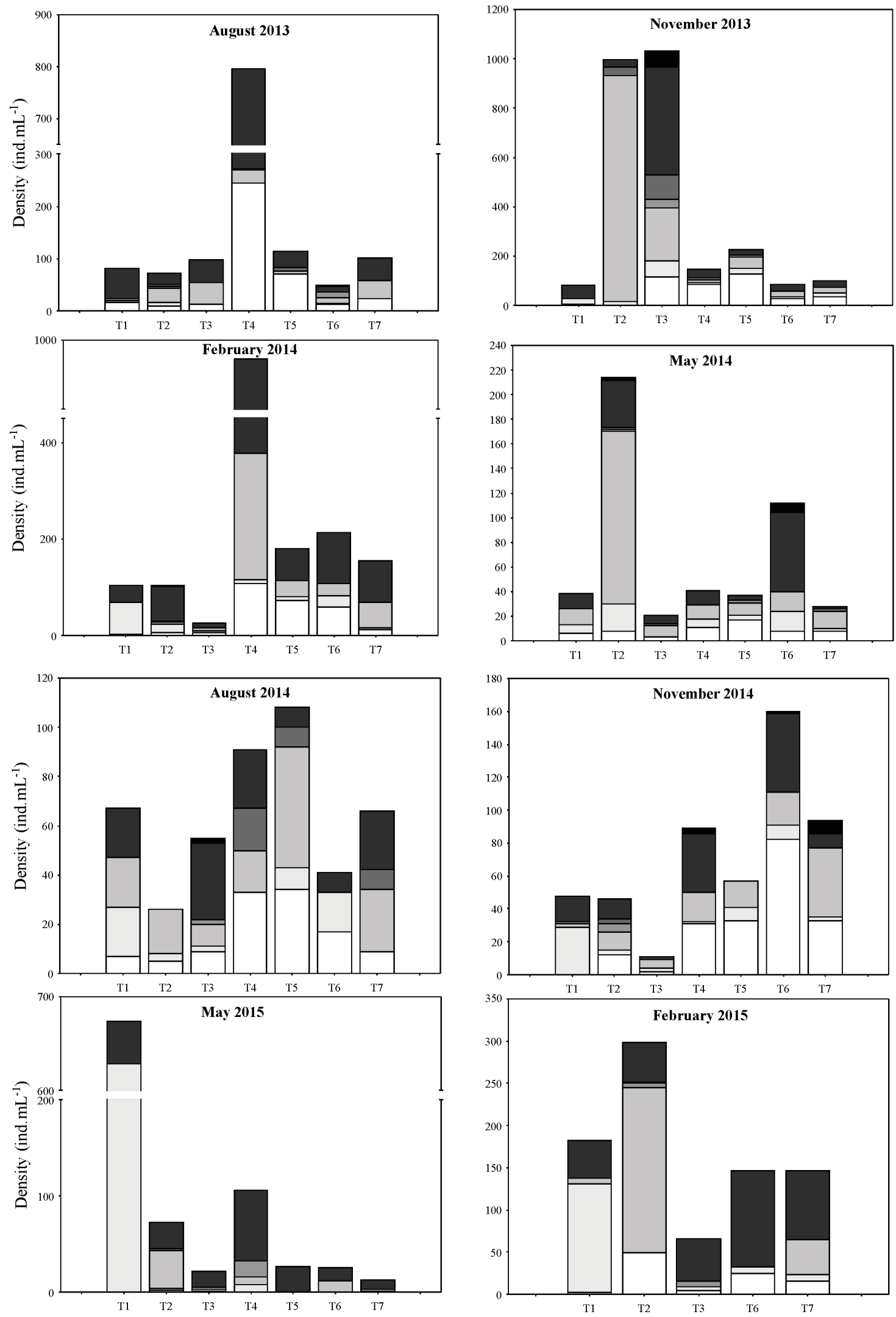

Euglenophyceae $\square$ Chrysophyceae $\square$ Chlorophyceae $\square$ Cyanobacteria $\square$ Bacillariophyceae

Figure 6. Density of phytoplankton taxonomic groups (ind. $\mathrm{ml}^{-1}$ ) in the main tributaries (T1 to T7) of the Paraná River sampled quarterly from August 2013 to May 2015. 


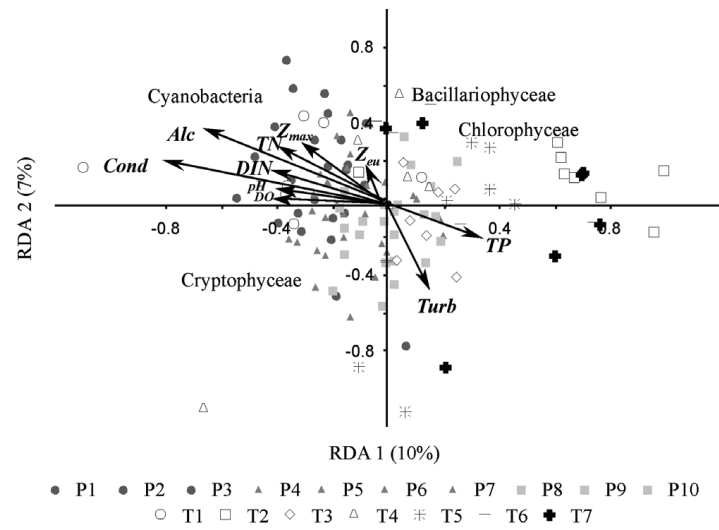

Figure 7. RDA ordination graph for the first two axes for phytoplankton density and abiotic variables (Maximum depth $\left(\mathrm{Z}_{\max }, \mathrm{m}\right)$; Euphotic zone (Zeu, m); Turbidity (Turb, NTU); Dissolved oxygen (DO, mg. $\mathrm{L}^{-1}$ ); Conductivity (Cond, $\mu \mathrm{S} . \mathrm{cm}^{-1}$ ); Alkalinity (Alc., mg. $\mathrm{L}^{-1}$ ); Total nitrogen (TN, $\mu \mathrm{g} . \mathrm{L}^{-1}$ ), Total phosphorus, TP, $\left.\mu \mathrm{g} \cdot \mathrm{L}^{-1}\right)$. Ten sampling stations along the longitudinal axis of the Paraná River (P1-P10) and main tributaries (T1- Paranapanema River; T2- Baia River; T3- Ivinhema River; T4- Ivai River; T5- Amambai River; T6- Iguatemi River; T7- Piquiri River). Upper stretch (P1, P2, P3, T1 and T2), middle stretch (P4, P5, P6, P7, T3, T4 and T5) and lower stretch (P8, P9, P10, T6 and T7).

2016). Moreover, the Paraná River basin is under the influence of climate events such as La Niña, which causes a reduction in rainfall volumes in southeast and south Brazil, interfering in the hydrosedimentological regime of the Paraná River (Rodrigues et al., 2009). The synergism between alterations imposed by upstream reservoirs and the climate likely influenced the low variation in the water levels of the Paraná River and the low temporal variation of environmental variables throughout the study period.

Floodplain studies indicate that the interchange of floods and droughts strongly influences the phytoplankton community, causing significant modifications on their ecological attributes (Train et al., 2000; Train \& Rodrigues, 1998; Devercelli, 2006; Bovo-Scomparin et al., 2013). Therefore, the absence of floods during our study likely influenced the low values of phytoplankton density and species richness and low temporal variation observed both in the Paraná River main channel and in the main tributaries.

The physical interactions, mainly flow velocity and light availability, drive phytoplankton growth in rivers, selecting species of small body size and that are better adapted to abrupt changes in light availability and resistant to mechanical shock.
Even in conditions of high light availability, the unidirectional and often turbulent flow hinders the establishment and development of phytoplankton species (Reynolds et al., 1994). The limitation imposed by those physical factors may explain the low values of phytoplankton species richness and densities found in our study. Moreover, along with the physical variables, the dilution effect of the Paraná River and low nutrient concentrations were likely also important, especially in the stretch located immediately upstream Porto Primavera reservoir.

The ability to grow under turbulent conditions, tolerate low light availability and be relatively resistant to mechanical shock, all favour the diatoms (Reynolds et al., 1994; Rodrigues et al., 2009), which were among the best represented groups along the Paraná River and tributaries. On the other hand, cyanobacteria commonly found in the Paraná River main channel usually find favourable conditions to their development in upstream reservoirs, constructed both at the Paraná and Paranapanema rivers (Borges et al., 2010; Bovo-Scomparin et al., 2013), from which their inocula are constantly transported downstream. This group of algae is considered undesirable and a protagonist in eutrophication events and toxin production, and may cause a decrease in species richness in the main river channel and associated lakes, leading to the biotic homogenization of the phytoplankton community, influencing species diversity and the energy transfer through the food web (Bovo-Scomparin et al., 2013; Rodrigues et al., 2015). The fact that the highest densities of this group of algae occurred at the left margin and center of the Paraná River, together with RDA results, indicate that cyanobacteria found in the main channel were probably dispersed mainly from the Paranapanema River (T1), which has its entire course regulated by reservoirs.

The upper stretch of the Paraná River is particularly exposed to the invasion risk of exotic and undesirable species, since passive dispersal of these species occur continuously via upstream cascading reservoirs (Thomaz et al., 2015). In addition to cyanobacterial dispersal which was previously registered in this area (Bovo-Scomparin et al., 2013), we detected the presence of the exotic speices Ceratium furcoides (Dinophyceae) in the Paraná River channel. Although occurring in low densities, its presence is cause for concern, considering that this species has the potential to cause the extinction of native species and interfere in the energy transfer 
up the food web (Jati et al., 2014; Cavalcante et al., 2016). Moreover, the presence of exotic or harmful species may impair the multiple uses of aquatic environments.

Cryptophyceae (Cryptomonas marsonii and Chroomonas acuta) and Chlorophyceae (Spermatosopsis exultans and Chlamydomonas spp.) represented an important portion of phytoplankton abundance both in the Paraná River and the tributaries. Their phenotypic plasticity, small size and rapid life cycle allow populations to remain in an environment even under loss processes such as transportation and predation (Reynolds, 2006; Rangel et al., 2009; Borges et al., 2010).

The tributaries in the last undammed stretch of the Paraná River are recognized as important for the input of nutrients and suspended particulate matter (Souza Filho, 2016), however, the high values of water discharge and the dilution effect of the Paraná River hindered the determination of the contribution of each tributary fro the phytoplankton community structure. The variations observed in phytoplankton attributes among tributaries may be attributed to differences regarding the geological origin, occupation of the drainage basin and anthropogenic impacts. The Paranapanema River (T1), which harbours cascading reservoirs, exports water containing high nitrogen concentration and elevated Cyanobacteria density to the Paraná River. RDA results showed a dissociation of $\mathrm{T} 1$ from the remaining tributaries, confirming the distinct contribution that this tributary exerts over this stretch of the Paraná River.

Tributaries located at the right margin of the Paraná River, such as Baia (T2), Ivinhema (T3), Amabai (T5) and Iguatemi (T6) rivers, drain the floodplain, allowing them to show a higher taxonomic complexity of the phytoplankton community, in response to the lower water flow and greater availability of light and nutrients. Finally, the tributaries at the left margin of the Paraná River, Ivaí (T4) and Piquiri (T7) rivers, have an elevated load of suspended solids, resulting from the drainage of a hydrographic basin strongly occupied with extensive agriculture, and the taxonomic groups that most contribute to phytoplankton density are the ones tolerant to low light availability, such as Bacillariophyceae e Cryptophyceae, which was evident in RDA results.

Considering the conspicuous importance of the tributaries in minimizing the gradual effects of oligotrophication in this stretch of the
Paraná River, it is crucial that these tributaries are maintained free of impoundments. Reservoir construction in these tributaries would extend the effects of oligotrophication and export of exotic and undesirable species throughout the area, causing species extinctions, biotic homogenization, besides hindering phytoplankton primary production, as it is observed in the region downstream Porto Primavera reservoir with the contribution of Paranapanema River (T1).

Therefore, we verified a reduction of the intense effect of upstream reservoirs along the longitudinal axis of the river, mainly considering nutrient concentrations and suspended particulate matter. Although the analysed phytoplankton attributes did not respond conspicuously to the reduction in the oligotrophication process with the increase in the distance from the dam, it was possible to verify an increase in the complexity of phytoplankton composition at the middle and lower stretches of the Paraná River, which was likely a consequence of an improvement of biotic conditions. Moreover, we believe that the tributaries have a key role on the input of inocula into the Paraná River main channel, positively influencing with the input of species, nutrients and particulate matter and negatively influencing with the export of undesirable and exotic species.

\section{Acknowledgements}

We would like to thank the project "Alto Rio Paraná: Longitudinal gradient of environmental variables and aquatic communities in the last undammed stretch between Porto Primavera and Itaipu Reservoirs" for the opportunity to develop this study, the Center for Research in Limnology, Ichthyology and Aquaculture of Maringá State University (Nupélia / UEM) and the Postgraduate Program in Ecology of Continental Aquatic Environments (PEA) for logistical and financial support. We are also grateful to the Brazilian Coordination for the Improvement of Higher Education Personnel (CAPES) for scholarships and to the National Council for Scientific and Technological Development (CNPq) for funding the project, to Nupélia / UEM Limnology Laboratory for providing the abiotic data used. Special thanks to the partners from Chico Mendes Institute (ICMBio) - Ilha Grande National Park, Sugar Mill Santa Terezinha (Usaçúcar) for logistic and financial support. 


\section{References}

AGOSTINHO, A.A., GOMES, L.C., THOMAZ, S.M. and HAHN, N.S. The upper Paraná River and its floodplain: main characteristics and perspectives for management and conservation. In: S.M. THOMAZ, A.A. AGOSTINHO and N.S. HAHN, eds. The Upper Paraná River its floodplain: physical aspects, ecology and conservation. Netherlands: Backhuys, 2004, pp. 381-393.

AGOSTINHO, A.A., PELICICE, F.M. and GOMES, L.C. Dams and the fish fauna of the Neotropical region: impacts and management related to diversity and fisheries. Brazilian Journal of Biology $=$ Revista Brasileira de Biologia, 2008, 68(4), 1119-1132, Supplement. PMid:19197482. http://dx.doi. org/10.1590/S1519-69842008000500019.

AMERICAN PUBLIC HEALTH ASSOCIATION APHA. Standard methods for the examination of water and wasterwater. 19th ed. Washington: APHA, 1995.

BICUDO, C.E.M. and MENEZES, M. Gêneros de algas de aguas continentais do Brasil: chave para identificação e descriçóes. São Carlos: RiMa, 2006.

BORGES, P.A.F. and TRAIN, S. Phytoplankton diversity in the Upper Paraná River floodplain during two years of drought (2000 and 2001). Brazilian Journal of Biology = Revista Brasileira de Biologia, 2009, 69(2), 637-647, Supplement. PMid:19738970. http:// dx.doi.org/10.1590/S1519-69842009000300018.

BORGES, P.A.F., TRAIN, S., DIAS, J.D. and BONECKER, C.C. Effects of fish farming on plankton structure in a Brazilian tropical reservoir. Hydrobiologia, 2010, 649(1), 279-291. http://dx.doi. org/10.1007/s10750-010-0271-2.

BORTOLINI, J.C., BOVO-SCOMPARIN, V.M., PAULA, A.C.M., MORESCO, G.A., REIS, L.M., JATI, S. and RODRIGUES, L.C. Composition and species richness phytoplankton in a subtropical floodplain lake: a long-term study. Acta Limnologica Brasiliensia, 2014a, 26(3), 296-305. http://dx.doi. org/10.1590/S2179-975X2014000300009.

BORTOLINI, J.C., MORESCO, G.A., PAULA, A.C.M., JATI, S. and RODRIGUES, L.C. Functional approach based on morphology as a model of phytoplankton variability in a subtropical floodplain lake: a long-term study. Hydrobiologia, 2016b, 767(1), 151-163. http://dx.doi.org/10.1007/ s10750-015-2490-z.

BORTOLINI, J.C., RODRIGUES, L.C., JATI, S. and TRAIN, S. Phytoplankton functional and morphological groups as indicators of environmental variability in a lateral channel of the Upper Paraná River floodplain. Acta Limnologica Brasiliensia, 2014b, 26(1), 98-108. http://dx.doi.org/10.1590/ S2179-975X2014000100011.

BORTOLINI, J.C., TRAIN, S. and RODRIGUES, L.C. Extreme hydrological periods: effects on phytoplankton variability and persistence in the subtropical floodplain. Hydrobiologia, 2016a, 763(1), 223-236. http://dx.doi.org/10.1007/s10750-0152378-y.

BOVO-SCOMPARIN, V.M. and TRAIN, S. Long-term variability of the phytoplankton community in an isolated floodplain lake of the Ivinhema River State Park, Brazil. Hydrobiologia, 2008, 610(1), 331-344. http://dx.doi.org/10.1007/s10750-008-9448-3.

BOVO-SCOMPARIN, V.M., TRAIN, S. and RODRIGUES, L.C. Influence of reservoirs to dispersion and seasonal variation of the phytoplankton community in the Upper Paraná River, Brazil. Hydrobiologia, 2013, 702(1), 115-127. http://dx.doi. org/10.1007/s10750-012-1313-8.

BRASIL, J. and HUSZAR, V.L.M. O Papel dos traços funcionais na ecologia do fitoplâncton continental. Oecologia Australis, 2011, 15(4), 799-834. http:// dx.doi.org/10.4257/oeco.2011.1504.04.

CAVALCANTE, K.P., CARDOSO, L.S., SUSSELLA, R. and BECKER, V. Towards a comprehension of Ceratium (Dinophyceae) invasion in Brazilian freshwaters: autecology of $C$. furcoides in subtropical reservoirs. Hydrobiologia, 2016, 771(1), 265-280. http://dx.doi.org/10.1007/s10750-015-2638-x.

COLE, G.A. Textbook of limnology. Illinois: Waveland Press, 1994.

DAJOZ, R. Princípios de Ecologia. Porto Alegre: Artmed, 2005.

DEVERCELLI, M. Phytoplankton of the Middle Parana' River during an anomalous hydrological period: a morphological and functional approach. Hydrobiologia, 2006, 563(1), 465-478. http://dx.doi. org/10.1007/s10750-006-0036-0.

GOLTERMAN, H.L., CLYMO, R.S. and OHNSTAD, M.A.M. Methods for physical and chemical analysis of freshwater. 2nd ed. Oxford: Blackwell Scientific Publication, 1978.

INSTITUTO BRASILEIRO DE GEOGRAFIA E ESTATÍSTICA - IBGE. Geografia do Brasil: região sul. Rio de Janeiro: IBGE, 1990.

JATI, S., RODRIGUES, L.C., BORTOLINI, J.C., PAULA, A.C.M., MORESCO, G.A., REIS, L.M., ZANCO, B.F. and TRAIN, S. First record of the occurrence of Ceratium furcoides (Levander) Langhans (Dinophyceae) in the Upper Paraná River Floodplain (PR/MS), Brazil. Brazilian Journal of Biology = Revista Brasileira de Biologia, 2014, 74(3), S235-S236, Supplement. http://dx.doi. org/10.1590/1519-6984.19313.

LEGENDRE, P. and LEGENDRE, L. Numerical ecology. 2nd ed. Amsterdam: Elsevier, 1998.

LUND, J.W.G., KIPLING, C. and LECREN, E.D. The inverted microscope method of estimating algal number and the statistical basis of estimating 
by counting. Hydrobiologia, 1958, 11(2), 143-170. http://dx.doi.org/10.1007/BF00007865.

MACKERETH, F.Y.H., HERON, J. and TALLING, J.F. Water analysis: some revised methods for limnologists. Freshwater Biological Association, 1978, 36, 1-120.

MARGALEF, R. Limnologia. Barcelona: Omega, 1983. $1010 \mathrm{p}$.

MATSUURA, P., PERBICHE-NEVES, G., FERREIRA, R.A.R. and NOGUEIRA, M.G. Changes in the phytoplankton structure downstream a large reservoir: effects of tributaries on the assemblages attributes. Biologia, 2015, 70(3), 320-327. http:// dx.doi.org/10.1515/biolog-2015-0037.

OKSANEN, J., BLANCHET, F.G., KINDT, R., LEGENDRE, P., MINCHIN, P.R., O'HARA, R.B., SIMPSON, G.L., SOLYMOS, P., STEVENS, M.H.H. and WAGNER, H. Vegan: Community Ecology Package. R package version 2.0- 4. Vienna: R Foundation for Statistical Computing, 2013 [viewed 17 May 2013]. Available from: http://CRAN.Rproject.org/package=vegan

PORTINHO, J.L., PERBICHE-NEVES, G. and NOGUEIRA, M.G. Zooplankton community and tributary effects in free-flowing section downstream a large tropical reservoir. International Review of Hydrobiology, 2016, 101(1-2), 48-56. http://dx.doi. org/10.1002/iroh.201501798.

R DEVELOPMENT CORE TEAM. Language and enviroment for statistical computing. Vienna: R Foundation for Statistical Computing, 2013 [viewed 17 May 2013]. Available from: http://www.Rproject.org

RANGEL, L.M., SILVA, L.H.S., ARCIFA, M.S. and PERTICARRARI, A. Driving forces of the diel distribution of phytoplankton functional groups in a shallow tropical lake (Lake Monte Alegre, Southeast Brazil). Brazilian Journal of Biology = Revista Brasileira de Biologia, 2009, 69(1), 75-85. PMid:19347148. http://dx.doi.org/10.1590/S151969842009000100009.

REYNOLDS, C.S. The ecology of phytoplankton. Cambridge: University Press, 2006.

REYNOLDS, C.S., DECY, J.P. and PADISÁK, J. Are phytoplankton dynamics in rivers so different from those in shallow lakes? Hydrobiologia, 1994, 289, 1-7. http://dx.doi.org/10.1007/BF00007404.

ROBERTO, M.C., SANTANA, N.F. and THOMAZ, S.M. Limnology in the Upper Paraná River floodplain: large-scale spatial and temporal patterns, and the influence of reservoirs. Brazilian Journal of Biology = Revista Brasileira de Biologia, 2009, 69(2), 717-725, Supplement. PMid:19738977. http:// dx.doi.org/10.1590/S1519-69842009000300025.

RODRIGUES, L.C., SIMÓES, N.R., BOVOSCOMPARIN, V.M., JATI, S., SANTANA, N.,
ROBERTO, M.C. and TRAIN, S. Phytoplankton alpha diversity as an indicator of environmentalchanges in a neotropical floodplain. Ecological Indicators, 2015, 48, 334-341. http://dx.doi.org/10.1016/j. ecolind.2014.08.009.

RODRIGUES, L.C., TRAIN, S., BOVOSCOMPARIN, V.M., JATI, S., BORSALLI, C.C.J. and MARENGONI, E. Interannual variability of phytoplankton in the main rivers of the Upper Paraná River floodplain, Brazil: influence of upstream reservoirs. Brazilian Journal of Biology = Revista Brasileira de Biologia, 2009, 69(2), 501516, Supplement. PMid:19738958. http://dx.doi. org/10.1590/S1519-69842009000300006.

SOUZA FILHO, E.E. Evaluation of the Upper Paraná River discharge controlled by reservoirs. Brazilian Journal of Biology $=$ Revista Brasileira de Biologia, 2009, 69(2), 707-716, Supplement. PMid:19738976. http://dx.doi.org/10.1590/S1519. 69842009000300024 .

SOUZA FILHO, E.E. The Porto Primavera Dam and the fluvial transport on the Porto São José Section, Parana river. Mercator, 2016, 15(4), 65-81. http:// dx.doi.org/10.4215/RM2016.1504.0005.

STANFORD, J.A. and WARD, J.V. Revisiting the serial discontinuity concept. Regulated Rivers: Research and Management, 2001, 17(4-5), 303-310. http://dx.doi. org/10.1002/rrr.659.

THOMAZ, S.M., MORMUL, R.P. and MICHELAN, T.S. Propagule pressure, invasibility of freshwater ecosystems by macrophytes and their ecological impacts: a review of tropical freshwater ecosystems. Hydrobiologia, 2015, 746(1), 39-59. http://dx.doi. org/10.1007/s10750-014-2044-9.

THOMAZ, S.M., PAGIORO, T.A., BINI, L.M., ROBERTO, M.C. and ROCHA, R.R.A. Limnological characterization of the aquatic environments and the influence of hydrometric levels. In: S.M. THOMAZ, A.A. AGOSTINHO and N.S. HAHN, eds. The Upper Parana River its floodplain: physical aspects, ecology and conservation. Leiden: Backhuys Publishers, 2004, pp. 75-102.

TRAIN, S. and RODRIGUES, L.C. Temporal fluctuations of the phytoplankton community of the Baía River, in the upper Paraná River floodplain, Mato Grosso do Sul, Brazil. Hydrobiologia, 1998, 361(1/3), 125-134. http:// dx.doi.org/10.1023/A:1003118200157.

TRAIN, S. and RODRIGUES, L.C. Phytoplankton assemblages. In: S.M. THOMAZ, A.A. AGOSTINHO and N.S. HAHN, eds. The Upper Paraná River its floodplain: physical aspects, ecology and conservation. Leiden: Backhuys Publishers, 2004, pp. 103-124.

TRAIN, S., OLIVEIRA, M.D. and QUEVEDO, M.T. Dinâmica sazonal da comunidade fitoplanctônica de 
um canal lateral (Canal Cortado) do Alto Rio Paraná (PR, Brasil). Acta Scientiarum, 2000, 22(2), 389-395.

UTERMÖHL, H. Zur Vervollkommung der quantitativen phytoplankton nmethodik. Germany: Mitteilungen der IVL, 1958, pp. 1-38. vol. 9.

WARD, J.V. and STANFORD, J.A. The serial discontinuity concept of lotic ecosystems. In: T.D. FONTAINE and S.M. BARTELL, eds. Dynamics of lotic ecosystems. Ann Arbor: Ann Arbor Scientific Publishers, 1983, pp. 29-42.

WINEMILLER, K.O., MCINTYRE, P.B., CASTELLO, L., FLUET-CHOUINARD, E., GIARRIZZO, T., NAM, S., BAIRD, I.G., DARWALL, W., LUJAN, N.K., HARRISON, I., STIASSNY, M.L.J., SILVANO, R.A.M., FITZGERALD, D.B., PELICICE, F.M., AGOSTINHO, A.A., GOMES,
L.C., ALBERT, J.S., BARAN, E., PETRERE JUNIOR, M., ZARFL, C., MULLIGAN, M., SULLIVAN, J.P., ARANTES, C.C., SOUSA, L.M., KONING, A.A., HOEINGHAUS, D.J., SABAJ, M., LUNDBERG, J.G., ARMBRUSTER, J., THIEME, M.L., PETRY, P., ZUANON, J., VILARA, G.T., SNOEKS, J., OU, C., RAINBOTH, W., PAVANELLI, C.S., AKAMA, A., SOESBERGEN, A. and SAENZ, L. Balancing hydropower and biodiversity in the Amazon, Congo, and Mekong. Science, 2016, 351(6269), 128-129. PMid:26744397. http://dx.doi.org/10.1126/science. aac7082.
Received: 04 April 2017 Accepted: 16 October 2017 